\title{
G × E Analysis of Rice Germplasm and NILs Having Bacterial Leaf Blight (BLB) Resistant Genes against Local Isolates of Xanthomonas oryzae at Diverse Agro-Ecological Zones
}

\author{
Halima Qudsia, Ayesha Bibi, Awais Riaz, Zulqarnain Haider*, Rana Ahsan Raza Khan, \\ Muhammad Akhter, Muhammad Sabar
}

Rice Research Institute, Kala Shah Kaku, Punjab, Pakistan

Email: *z.haider.breeder@gmail.com

How to cite this paper: Qudsia, H., Bibi, A., Riaz, A., Haider, Z., Khan, R.A.R., Akhter, M. and Sabar, M. (2019) G $\times$ E Analysis of Rice Germplasm and NILs Having Bacterial Leaf Blight (BLB) Resistant Genes against Local Isolates of Xanthomonas oryzae at Diverse Agro-Ecological Zones. Advances in Microbiology, 9, 454-466. https://doi.org/10.4236/aim.2019.95027

Received: April 8, 2019

Accepted: May 14, 2019

Published: May 17, 2019

Copyright $\odot 2019$ by author(s) and Scientific Research Publishing Inc. This work is licensed under the Creative Commons Attribution International License (CC BY 4.0).

http://creativecommons.org/licenses/by/4.0/

\begin{abstract}
Rice is food for more than half of the world population and the most consumable cereal in most of the countries. Pakistan is the fifth largest exporter of rice. However, Bacterial leaf blight (BLB) caused by Xanthomonas oryzae pv. oryzae is the most devastating and serious threat to rice production in many countries of the world including Pakistan. To combat this disease, innate genetic resistance of the plant plays vital role along with being environmentally friendly and economical. In this study, thirty-one (31) Near Isogenic Lines (NILs) having Xa4, xa5, Xa7, xa13 and Xa21 reported BLB tolerant genes and 34 locally developed rice lines were investigated under natural field conditions at three agro-ecologically different locations with highest disease occurrence records (BLB hotspots) viz., Sheikhupura, Hafizabad and Gujranwala, Punjab, Pakistan in order to assess their respective genetic resistance and $\mathrm{G} \times \mathrm{E}$ interactions against the disease. Thirty-one (31) lines were categorized under resistant cluster, twenty-eight (28) were moderately resistant, six (6) were moderately susceptible and one (susceptible check) was in susceptible category. Grouping of different lines/varieties under same cluster shows their significantly similar response against BLB disease in corresponding environment. Among the studied NILs, only one line showed polymorphism for all five resistant genes, two lines had four; seven lines had three genes, seven lines showed di-genic while five lines showed mono-genic polymorphism. These resistant lines with multiple-genes for BLB resistance can be evolved as a new BLB resistant variety and also be utilized as donor parent in breeding programs for developing new cultivars with horizontal resistance against more than one target pathotypes and environments. Xa4 and $x a 13$
\end{abstract}


were found to deliver significant resistance against the local pathotypes in studied germplasm and NILs.

\section{Keywords}

Rice, Oryza sativa L., Genotypic Environment Interaction, Bacterial Leaf Blight, Xanthomonas oryzae pv. oryzae

\section{Introduction}

Rice is one of the most important staple food of over half of the world's population and about $90 \%$ of the world rice is grown and consumed in Asian continent [1]. Pakistan is the fifth largest rice exporter comprising mainly of basmati rice. Despite rice importance in Pakistan and all over the world, this crop is vulnerable to many biotic and abiotic stresses chiefly because of the absence of resistant/tolerant genes. Among the biotic stresses, bacterial leaf blight (BLB) disease is highly threatening all over the rice world. This disease is caused by rod-shaped bacterium Xanthomonas oryzae pv. oryzae [2]. In South Asia, BLB is the most serious disease in irrigated and lowland fields [3] because of conducive to environment and following repeated cultivation [4]. Management of many improved and high yielding varieties with high nitrogen levels and close spacing expose the crop defenseless against the disease [5]. This disease is the most devastating and serious threat to rice production. High humidity, wind and rainfall favor the development and spread of this disease. Symptoms of water-soaked, yellowish stripes along the leaf margins can be observed at all stages of rice plants leading to yield loss typically ranging from $20 \%-30 \%$ but in severe cases as high as $80 \%$ reduction [3] [6].

High spread of disease in favorable conditions make BLB more difficult to manage through conventional control methods such as chemical sprays. To combat this disease, innate genetic resistance of the plant plays vital role along with being environmentally friendly and economical. Development of resistant cultivars against BLB force that the bacterium to modify itself hence breaking the host resistance. Therefore, it is very critical to continually explore new resistance sources against the ever-changing bacterial pathogen [7]. As chemical control of the disease is not much effective, and also causing environmental hazards, the deployment of resistant varieties has been considered as the most effective way to control the disease [8]. Using resistant varieties not only reduce the cost of chemicals being used for the management of the disease but also an environmentally friendly approach. In the case of BLB resistance, cultivated rice and the wild relatives have been identified with 35 BLB resistance genes [6] [8] [9].

Cluster analysis forms different groups or clusters on the basis of similar response of lines/varieties but it does not necessarily mean that all entries in a 
group have same response or origin. However, this analysis provides helpful insight that could be used in the development of resistant varieties. Clusters can identify sources of new resistance along with high yield factor to overcome the altering pathogen and environment, and also study the mechanism of resistance.

Therefore, the present study was carried out with the objective to evaluate 66 local and exotic rice lines/varieties and various Near Isogenic Lines (NILs) having known resistant genes against BLB. Three hot spot sites with higher disease incidence recorded in past years were selected for the screening under natural conditions.

\section{Materials \& Methods}

\subsection{Experimental Sites and Rice Lines/Varieties}

Three hot spot sites of bacterial leaf blight disease with naturally higher disease incidence were selected for the experiment. These sites were in Gujranwala, Sheikhupura and Hafizabad, Punjab, Pakistan. In the experiment, sixty-five (65) rice lines/varieties including 34 locally developed rice lines, 31 NILs and one commercial variety Basmati Super as susceptible check was cultivated at farmer's fields in RCBD design.

\subsection{Monitoring and Evaluation}

Seeds were sown on dry land raised beds $(1 \mathrm{ft} . \times 1 \mathrm{ft}$. for each entry with $1 \mathrm{ft}$. interval). Thin layer of fine crushed decayed farmyard manure (FYM) was spread over them and then watered with a hand sprinkler thrice a day. After the 4th day of nursery sprouting, field was flooded for the first time. Thirty-five (35) days old plants were transplanted having 9 inches plant to plant and row to row distance. All the recommended agronomic practices followed throughout the season from sowing to harvest of the crop. The disease incidence was recorded by using scale given as Table 1.

\subsection{Statistical Analysis}

The replication means of each genotype response to disease were subjected to statistical analysis. Cluster Analysis (CA) and Principal Component Analysis (PCA) were performed for the genotypes grouping and to identify the response toward the prevalent BLB pathotypes at three different locations, respectively using Minitab software.

Table 1. Scale for BLB (for field test, lesion area).

\begin{tabular}{ccc}
\hline Score & Percent Disease (\%) & Host Response \\
\hline 1 & $1-5$ & Highly Resistant \\
3 & $6-12$ & Resistant \\
5 & $13-25$ & Moderately Resistant \\
7 & $26-50$ & Moderately Susceptible \\
9 & $51-100$ & Susceptible \\
\hline
\end{tabular}




\subsection{Plant Materials}

Sixty-seven (67) genotypes comprising of local and exotic origin, thirty near isogenic lines (NILs) as positive resistant gene checks and IR24 \& Super Basmati as negative gene check were in this study. For this purpose, leaf samples were taken from rice seedling grown in the growth chamber of MAS lab of Rice Research Institute, Kala Shah Kaku, and Pakistan used for isolating genomic DNA.

\subsection{Genomic DNA Extraction}

Rice seeds of all the genotypes were grown in germination jars under controlled environment (temperature $35^{\circ} \mathrm{C}$ and humidity $80 \%-85 \%$ ) of growth chamber. Young leaves were taken for DNA extraction at seedling stage using Miniprep protocol. Few leaves (10 - 15 days old) were ground in liquid nitrogen and then added $800 \mathrm{ul}$ extraction buffers. Prepare $100 \mathrm{ml}$ of DNA extraction buffer, $1 \mathrm{M}$ Tris HCI (10 ml), $0.25 \mathrm{M}$ EDTA $(20 \mathrm{ml}), \mathrm{NaCl}(2.9 \mathrm{~g})$, sodium bisulphate $(0.38$ g), $20 \% \mathrm{SDS}(6.25 \mathrm{ml})$ and deionized $\mathrm{H}_{2} \mathrm{O}(63.75 \mathrm{ml})$ were used. The samples were incubated for 20 minutes at $65^{\circ} \mathrm{C}$ in water bath. Then equal volume of Chloroform: Isoamyl alcohol (24:1) was added. Centrifugation was carried out it for 8 minutes at $11,000 \mathrm{rpm}$. In a new tube $(1.5 \mathrm{ml}), 500 \mathrm{ul}$ of supernatant was taken and $1000 \mathrm{ul}$ of chilled isopropanol $\left(-20^{\circ} \mathrm{C}\right)$ added. The samples were now centrifuged at 10,000 rpm for 10 minutes. Aqueous solution was discarded carefully so that pellet does not get damaged or lost. Pellet was then washed with $1000 \mathrm{ul}$ of $70 \%$ ethanol and re-suspended in $100 \mu \mathrm{l}$ of TrisEDTA (TE) buffer.

To check the DNA quality of isolated genomic DNA, 3 ul of stock DNA mixed with $2 \mathrm{ul}$ of loading dye was loaded in $0.8 \%$ agarose gel prepared in $1 \mathrm{X}$ TAE buffer ( $\mathrm{pH}$ 8.5). After 35 minutes run at 80 Volts, the genomic DNA concentration was observed using gel documentation system. Lambda DNA was used for estimation of DNA concentration of stock solution. Finally, the working dilutions were prepared with $30-50 \mathrm{ng} / \mathrm{ul}$ DNA concentration and stored at $4^{\circ} \mathrm{C}$.

\subsection{PCR Amplification}

DNA fragment carrying Xa4, $\mathrm{x} a 5$ and Xa21 was amplified using tightly linked and co-segregated primers "MP1, RM122, and pTA 248" respectively (Table 2). The sequences (forward \& reverse) of these marker primers are given in Table 2. A reaction volume of $10 \mu \mathrm{l}$ was used for PCR amplification, containing $2 \mu \mathrm{DNA}$ (30 ng/ $\mu \mathrm{l}), 0.75 \mu \mathrm{l}$ of forward Primer and $0.75 \mu \mathrm{l}$ of reverse primer (10 p moles/ $\mu \mathrm{l})$, $1.5 \mu \mathrm{l}$ of double distilled water and $5 \mu \mathrm{l}$ of green master mix (Thermo, USA). Amplification was performed in a programmed thermocycler (Kyratech, Australia) with initial denaturation at $95^{\circ} \mathrm{C}$ for $5 \mathrm{~min}$, followed by 35 denaturation cycles at $95^{\circ} \mathrm{C}$ for $1 \mathrm{~min}$, annealing at $54^{\circ} \mathrm{C}$ for $1 \mathrm{~min}$, elongation at $72^{\circ} \mathrm{C}$ for 2 min, and final extension at $72^{\circ} \mathrm{C}$ for $5 \mathrm{~min}$. Amplified products of $\mathrm{Xa4}, \mathrm{xa}$, and $X a 21$ were subjected to electrophoresis in 3.5\% agarose gel run in 0.5X TAE buffer. Ethidium bromide $(10 \mu \mathrm{g} / \mathrm{mL})$ was used to stain the gel, followed by gel documentation(UV Tech, USA) and identified for the presence (++), absence (--) of BLB gene linked DNA fragment [10]. 
Table 2. Detailed information of markers and primer sequences for each studied gene.

\begin{tabular}{|c|c|c|c|c|c|c|}
\hline $\begin{array}{l}\text { Target } \\
\text { Gene }\end{array}$ & Marker & Primer sequences & $\begin{array}{l}\text { Annealing } \\
\text { Temp. }\end{array}$ & $\begin{array}{l}\text { Resistant } \\
\text { Band (bp) }\end{array}$ & $\begin{array}{l}\text { Susceptible } \\
\text { Band (bp) }\end{array}$ & References \\
\hline Xa4 & $\mathrm{MP} 1+\mathrm{MP} 2$ & $\begin{array}{l}\text { F-5'-ATCGATCGATCTTCACGAGG-3' } \\
\text { R-5'-dTGCTATAAAAGGCATTCGGG-3' }\end{array}$ & $55^{\circ} \mathrm{C}$ & 150 & 120 & $\begin{array}{c}\text { Ma Bo Jun et al., } \\
1992\end{array}$ \\
\hline$x a 5$ & RM122 (F + R) & $\begin{array}{l}\text { F-5'-GAGTCGATGTAATGTCATCAGTGC-3' } \\
\text { R-5'-GAAGGAGGTATCGCTTTGTTGGAC-3' }\end{array}$ & $56^{\circ} \mathrm{C}$ & 240 & 230 & Chen et al., 1997 \\
\hline Xa7 & M5 $(\mathrm{F}+\mathrm{R})$ & $\begin{array}{l}\text { F-5'-CGATCTTACTGGCTCTGCAACTCTGT-3' } \\
\text { R-5'-GCATGTCTGTGTCGATTCGTCCGTACGA-3' }\end{array}$ & $55^{\circ} \mathrm{C}$ & 294,320 & 1170 & $\begin{array}{l}\text { Porter et al., } \\
\quad 2003\end{array}$ \\
\hline$x a 13$ & $x a 13(F+R)$ & $\begin{array}{l}\text { F-5'-CCTGATATGTGAGGTAGT-3' } \\
\text { R-5'-GAGAAAGGCTTAAGTGC-3' }\end{array}$ & $57^{\circ} \mathrm{C}$ & 560 & 250 & Chu et al., 2006 \\
\hline$X a 21$ & pTA248 $(\mathrm{F}+\mathrm{R})$ & $\begin{array}{c}\text { F-5'-AGACGCGGAAGGGTGGTTCCCGGA-3' } \\
\text { R-5'-AGACGCGGTAATCGAAGATGAAA-3' }\end{array}$ & $56^{\circ} \mathrm{C}$ & 925,1040 & 730 & $\begin{array}{c}\text { Ronald et al., } \\
1992\end{array}$ \\
\hline
\end{tabular}

\subsection{Data Analysis}

The amplified fragments of all the rice genotypes were scored by comparing with respective resistance (IRBB near-isogenic lines) and susceptible (IR24) bands. The data were scored using “++/--" signs for presence/absence of target gene respectively [11] as depicted in Table 3.

\section{Results and Discussions}

Disease scoring was done by following the Standard Evaluation System (SES) of Rice developed by International Rice Research Institute (IRRI), Philippines.

Results of genotypic and environmental interactions among studied lines, genes and three hotspots were comprehended using Cluster Analysis (CA) and Genotypic and Environment International (GEI) analysis which divided the lines/varieties in four clusters or groups named as resistant, moderately resistant, moderately susceptible, and susceptible depending on disease scoring over environments/hotspots. Thirty-one (31) lines were categorized under resistant cluster, twenty-eight (28) were moderately resistant, six (6) were moderately susceptible and one (susceptible check) was in susceptible category (Figure 1 and Table 4). Grouping of different lines/varieties under the same cluster shows their significantly similar response against BLB disease in corresponding environment.

\subsection{Genotypic Evaluation}

Among the studied NILs, only one line showed polymorphism for all five resistant genes, two lines had four; seven lines had three genes, seven lines showed di-genic while five lines showed mono-genic polymorphism. These lines with multiple-genes for BLB resistance can be evolved as a new BLB resistant variety and also be utilized as donor parent in breeding programs for developing new cultivars with horizontal resistance against more than one target pathotypes and environments.

Sixty-seven (67) genotypes including local cultivars, IRBB lines carrying BLB 
Table 3. Xa genes status of IRBB lines: Presence (++); Absence (--).

\begin{tabular}{|c|c|c|c|c|c|c|}
\hline Sr. No & DESIGNATION & $X a 4$ & $x a 5$ & $X a 7$ & $x a 13$ & $X a 21$ \\
\hline 1 & IRBB1 & -- & -- & -- & -- & -- \\
\hline 2 & IRBB3 & -- & -- & -- & -- & -- \\
\hline 3 & IRBB4 & ++ & -- & -- & -- & -- \\
\hline 4 & IRBB5 & -- & ++ & -- & -- & -- \\
\hline 5 & IRBB7 & -- & -- & ++ & -- & -- \\
\hline 6 & IRBB8 & -- & -- & -- & -- & -- \\
\hline 7 & IRBB10 & -- & -- & -- & -- & -- \\
\hline 8 & IRBB11 & -- & -- & -- & -- & -- \\
\hline 9 & IRBB13 & -- & -- & -- & ++ & -- \\
\hline 10 & IRBB14 & -- & -- & -- & -- & -- \\
\hline 11 & IRBB21 & -- & -- & -- & -- & ++ \\
\hline 12 & IRBB23 & -- & -- & -- & -- & -- \\
\hline 13 & IRBB50 & ++ & ++ & -- & -- & -- \\
\hline 14 & IRBB51 & ++ & -- & -- & ++ & -- \\
\hline 15 & IRBB52 & ++ & -- & -- & -- & ++ \\
\hline 16 & IRBB53 & -- & ++ & -- & ++ & -- \\
\hline 17 & IRBB54 & -- & ++ & -- & -- & ++ \\
\hline 18 & IRBB55 & -- & -- & -- & ++ & ++ \\
\hline 19 & IRBB56 & ++ & ++ & -- & ++ & -- \\
\hline 20 & IRBB57 & ++ & ++ & -- & -- & ++ \\
\hline 21 & IRBB58 & ++ & -- & -- & ++ & ++ \\
\hline 22 & IRBB59 & -- & ++ & -- & ++ & ++ \\
\hline 23 & IRBB60 & ++ & ++ & -- & ++ & ++ \\
\hline 24 & IRBB61 & ++ & ++ & ++ & -- & -- \\
\hline 25 & IRBB62 & ++ & -- & ++ & -- & ++ \\
\hline 26 & IRBB63 & -- & ++ & ++ & ++ & -- \\
\hline 27 & IRBB64 & ++ & ++ & ++ & -- & ++ \\
\hline 28 & IRBB65 & ++ & -- & ++ & ++ & ++ \\
\hline 29 & IRBB66 & ++ & ++ & ++ & ++ & ++ \\
\hline 30 & IRBB67 & ++ & -- & ++ & -- & -- \\
\hline
\end{tabular}

resistant genes as single/in combinations; and F1 crosses along with resistant and susceptible controls were screened against 5 BLB resistance genes under epiphytotic conditions of hotspot locations during the year. Results depicted in Table 3 show the gene status of IRBB lines being used for studying the interaction of single or multiple genes for BLB disease resistance in three different environmental conditions. Forward and reverse sequences of the primers used for 
Table 4. Grouping of rice lines/varieties in different clusters based on their response to disease.

\begin{tabular}{|c|c|c|c|}
\hline Cluster No. & Score & Host Response & Lines/Varieties \\
\hline 1 & 3 & $\begin{array}{l}\text { Resistant } \\
\text { (Cluster I) }\end{array}$ & $\begin{array}{c}\text { 00521/IRBB5-16, 00521/IRBB5-17, Super Bas./IRBB-21//Super Bas.-19, } \\
\text { Bas.2000/IRBB-58//IRBB-58-20, Super Bas./IRBB-21//Super Bas.-23, RRI-7-1, RRI-7-2, } \\
\text { RRI-7-3, RRI-7-5, RRI-7-6, RRI-7-8, RRI-7-12, RRI-7-13, PKBB 1501, PKBB 1502, } \\
\text { PKBB 1503, PKBB 1506, IRBB1, IRBB3, IRBB5, IRBB11, IRBB14, IRBB51, IRBB52, } \\
\text { IRBB53, IRBB55, IRBB58, IRBB66 }\end{array}$ \\
\hline 2 & 5 & $\begin{array}{l}\text { Moderately Resistant } \\
\quad \text { (Cluster II) }\end{array}$ & $\begin{array}{c}\text { 00515/IRBB13, 00515/IRBB21-13, 00515/IRBB21-14, 00515/IRBB59, 00515/IRBB7, } \\
\text { Bas.2000/IRBB-58//IRBB-58-21, Bas.2000/IRBB-58//IRBB-58-22, RRI-7-10, RRI-7-11, } \\
\text { PKBB 1504, PKBB 1505, PKBB 1507, PKBB 1508, PKBB 1509, PKBB 1510, IRBB4, } \\
\text { IRBB8, IRBB10, IRBB13, IRBB23, IRBB50, IRBB54, IRBB56, IRBB57, IRBB59, IRBB60, } \\
\text { IRBB61, IRBB62, IRBB63, IRBB65, IRBB67 }\end{array}$ \\
\hline 3 & 7 & $\begin{array}{l}\text { Moderately Susceptible } \\
\quad \text { (Cluster III) }\end{array}$ & $\begin{array}{c}\text { Bas.2000/IRBB-58//IRBB-58-20, RRI-7-4, RRI-7-7, RRI-7-9, IRBB64, RRI-7-9, PKBB } \\
\text { 1507, IRBB23, IRBB57, PKBB 1508, IRBB8, PKBB 1509, PKBB } 1510\end{array}$ \\
\hline 4 & 9 & $\begin{array}{l}\text { Susceptible } \\
\text { (Cluster IV) }\end{array}$ & IRBB7, IR24 \& Check (Super Basmati) \\
\hline
\end{tabular}

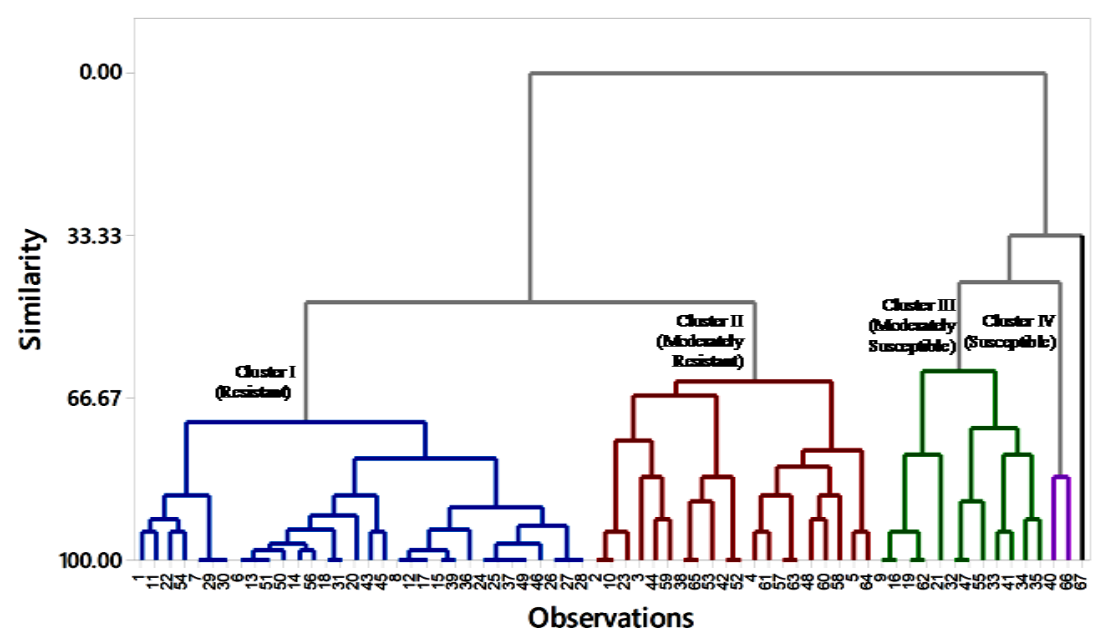

Figure 1. Dendrogram showing clusters of studied genotypes on the basis of response against BLB disease at three locations; entry 67 is Super Basmati as susceptible check

the confirmation of respective BLB resistance genes is also given in Table 2. All the studied genotypes were screened for the presence or absence of five BLB resistance genes using PCR based markers respectively linked to these genes. The PCR results for the BLB resistant genes estimated by visualizing amplicons in different base pairs of positive fragments respectively. Results of the gene status of IRBB lines clearly showed that the primer pairs used in this study can be effectively used for the confirmation of the BLB resist resistance genes. Data depicted in Table 3 to clearly confirm that IRBB 1, 3, 8, 10, 11, 14 and 23 did not show polymorphism indicating that these lines do not possess the target genes. During the polymorphic survey out of total 30 studied near isogenic lines, only one line showed polymorphism for all five resistance genes, 2 lines were tri-genic, 7 lines showed digenic while 5 lines showed monogenic polymorphism.

As depicted in Table 5, BLB disease incidence (DI) ranged from $2.67 \%$ $46.67 \%$ for varieties and NILs at three locations on average basis, where variety 
Table 5. Genotypes with their disease incidence (\%) record at studied three locations.

\begin{tabular}{|c|c|c|c|c|c|}
\hline & Genotypes name & Hafizabad & $\begin{array}{c}\text { Kala Shah } \\
\text { Kaku }\end{array}$ & Gujranwala & $\begin{array}{c}\text { Average } \\
\text { (genotypes) }\end{array}$ \\
\hline 1 & 00515/IRBB13 & 20 & 5 & 15 & 13.33 \\
\hline 2 & 00515/IRBB21 & 3 & 30 & 20 & 17.67 \\
\hline 3 & 00515/IRBB21 & 10 & 35 & 30 & 25.00 \\
\hline 4 & 00515/IRBB59 & 20 & 20 & 10 & 16.67 \\
\hline 5 & 00521/IRBB 5 & 10 & 20 & 10 & 13.33 \\
\hline 6 & 00521/IRBB 5 & 3 & 5 & 5 & 4.33 \\
\hline 7 & 00515/IRBB 7 & 20 & 10 & 5 & 11.67 \\
\hline 8 & Super Bas./IRBB-21// Super Bas. & 10 & 3 & 10 & 7.67 \\
\hline 9 & Bas.2000/IRBB-58//IRBB-58 & 40 & 30 & 30 & 33.33 \\
\hline 10 & Bas.2000/IRBB-58//IRBB-58 & 3 & 30 & 20 & 17.67 \\
\hline 11 & Bas.2000/IRBB-58//IRBB-58 & 20 & 5 & 10 & 11.67 \\
\hline 12 & Super Bas./IRBB-21//Super Bas. & 10 & 3 & 10 & 7.67 \\
\hline 13 & RRI-7-1 & 3 & 5 & 5 & 4.33 \\
\hline 14 & RRI-7-2 & 3 & 3 & 3 & 3.00 \\
\hline 15 & RRI-7-3 & 10 & 5 & 10 & 8.33 \\
\hline 16 & RRI-7-4 & 40 & 30 & 30 & 33.33 \\
\hline 17 & RRI-7-5 & 10 & 3 & 10 & 7.67 \\
\hline 18 & RRI-7-6 & 3 & 0 & 5 & 2.67 \\
\hline 19 & RRI-7-7 & 40 & 35 & 30 & 35.00 \\
\hline 20 & RRI-7-8 & 10 & 3 & 5 & 6.00 \\
\hline 21 & RRI-7-9 & 40 & 20 & 40 & 33.33 \\
\hline 22 & RRI-7-10 & 20 & 10 & 15 & 15.00 \\
\hline 23 & RRI-7-11 & 3 & 25 & 20 & 16.00 \\
\hline 24 & RRI-7-12 & 3 & 5 & 10 & 6.00 \\
\hline 25 & RRI-7-13 & 3 & 5 & 10 & 6.00 \\
\hline 26 & РКBB 1501 & 3 & 5 & 15 & 7.67 \\
\hline 27 & РКBB 1502 & 3 & 5 & 15 & 7.67 \\
\hline 28 & РКBB 1503 & 3 & 5 & 15 & 7.67 \\
\hline 29 & РКBB 1504 & 20 & 10 & 5 & 11.67 \\
\hline 30 & РКBB 1505 & 20 & 10 & 5 & 11.67 \\
\hline 31 & РКBB 1506 & 3 & 0 & 5 & 2.67 \\
\hline 32 & РКBB 1507 & 40 & 30 & 10 & 26.67 \\
\hline 33 & РКBB 1508 & 40 & 10 & 15 & 21.67 \\
\hline 34 & РКBB 1509 & 40 & 15 & 20 & 25.00 \\
\hline 35 & PKBB 1510 & 40 & 20 & 25 & 28.33 \\
\hline 36 & IRBB 1 & 10 & 5 & 15 & 10.00 \\
\hline
\end{tabular}




\section{Continued}

\begin{tabular}{|c|c|c|c|c|c|}
\hline 37 & IRBB3 & 3 & 5 & 10 & 6.00 \\
\hline 38 & IRBB4 & 3 & 10 & 30 & 14.33 \\
\hline 39 & IRBB5 & 10 & 5 & 10 & 8.33 \\
\hline 40 & IRBB7 & 70 & 30 & 20 & 40.00 \\
\hline 41 & IRBB8 & 40 & 10 & 10 & 20.00 \\
\hline 42 & IRBB 10 & 3 & 20 & 30 & 17.67 \\
\hline 43 & IRBB 11 & 3 & 10 & 0 & 4.33 \\
\hline 44 & IRBB13 & 20 & 30 & 25 & 25.00 \\
\hline 45 & IRBB 14 & 3 & 10 & 5 & 6.00 \\
\hline 46 & IRBB 21 & 3 & 8 & 10 & 7.00 \\
\hline 47 & IRBB 23 & 40 & 30 & 10 & 26.67 \\
\hline 48 & IRBB 50 & 20 & 20 & 25 & 21.67 \\
\hline 49 & IRBB 51 & 3 & 5 & 10 & 6.00 \\
\hline 50 & IRBB 52 & 3 & 3 & 5 & 3.67 \\
\hline 51 & IRBB 53 & 3 & 5 & 5 & 4.33 \\
\hline 52 & IRBB 54 & 3 & 20 & 30 & 17.67 \\
\hline 53 & IRBB 55 & 3 & 10 & 20 & 11.00 \\
\hline 54 & IRBB 56 & 20 & 10 & 10 & 13.33 \\
\hline 55 & IRBB 57 & 40 & 30 & 20 & 30.00 \\
\hline 56 & IRBB 58 & 3 & 5 & 3 & 3.67 \\
\hline 57 & IRBB 59 & 20 & 30 & 15 & 21.67 \\
\hline 58 & IRBB 60 & 10 & 20 & 20 & 16.67 \\
\hline 59 & IRBB 61 & 20 & 25 & 30 & 25.00 \\
\hline 60 & IRBB 62 & 20 & 15 & 20 & 18.33 \\
\hline 61 & IRBB 63 & 20 & 25 & 10 & 18.33 \\
\hline 62 & IRBB 64 & 40 & 35 & 30 & 35.00 \\
\hline 63 & IRBB 65 & 20 & 30 & 15 & 21.67 \\
\hline 64 & IRBB 66 & 10 & 15 & 10 & 11.67 \\
\hline 65 & IRBB 67 & 3 & 10 & 30 & 14.33 \\
\hline 66 & IR 24 & 70 & 40 & 30 & 46.67 \\
\hline \multirow[t]{2}{*}{67} & Check & 20 & 50 & 30 & 33.33 \\
\hline & Average (locations) & 16.84 & 15.39 & 15.54 & 15.92 \\
\hline
\end{tabular}

Highly Resistant $=1 \%-5 \%$; Resistant $=6 \%-12 \%$; Moderately Resistant $=13 \%-25 \%$; Moderately Susceptible $=26 \%-50 \%$; Susceptible $=51 \%-100 \%$.

IR 24 showed maximum (46.27\%) disease incidence percentage in average at three locations followed by IRBB7 (40\%), IRBB64 \& RRI7-6 (35\%) and susceptible check (33.3\%) among the studied germplasm and NILs. On the other hand, minimum disease incidence percentage was recorded for PKBB1506 \& RRI7-6 (2.67\%) on average at three locations, followed by RRI7-2 (3\%), IRBB52 \& IRBB58 (3.67\%), four lines with 4.33\% DI percentage, 5 lines with 6\% DI and 7 
lines with 7\% DI on average basis. Likewise, percentage DI for each location on average basis for all studied genotypes was ranged from 70\% for IR64 at Hafizabad to minimum of $0 \%$ (no DI observed) for IRBB11 (at Gujranwala location) while RRI7-6 and PKBB1506 (at KSK location). On average, the maximum DI percentage (16.84) was recorded at Hafizabad location, followed by Gujranwala (15.54\%) and KSK (15.39\%).

\subsection{GEI and Biplot Analysis}

Biplot view (Figure 2) of GEI analysis shows the significantly different performances of all the three target hotspot locations with respect to the disease responses of all the studied genotypes. Two locations i.e. Shiekhupura and Gujranwala, among all the three locations, showed close proximities in disease response and out of these two locations, Gujranwala location showed more variability while the sheikhupura location showed more stability as compared to one another. The third locations, showed maximum variability for the disease incidence as indicated by the longest vector as depicted in biplot (Figure 2).

Center of the co-centric rings shows the average of the disease incidence data at all the three studied locations. Farther the lines from the center, the more diverse with respect to disease incidence. The check genotype showed maximum disease incidence in all the three locations while the disease incidence was more in other two locations as compared to Hafizabad location. Likewise, entry no 66, showed

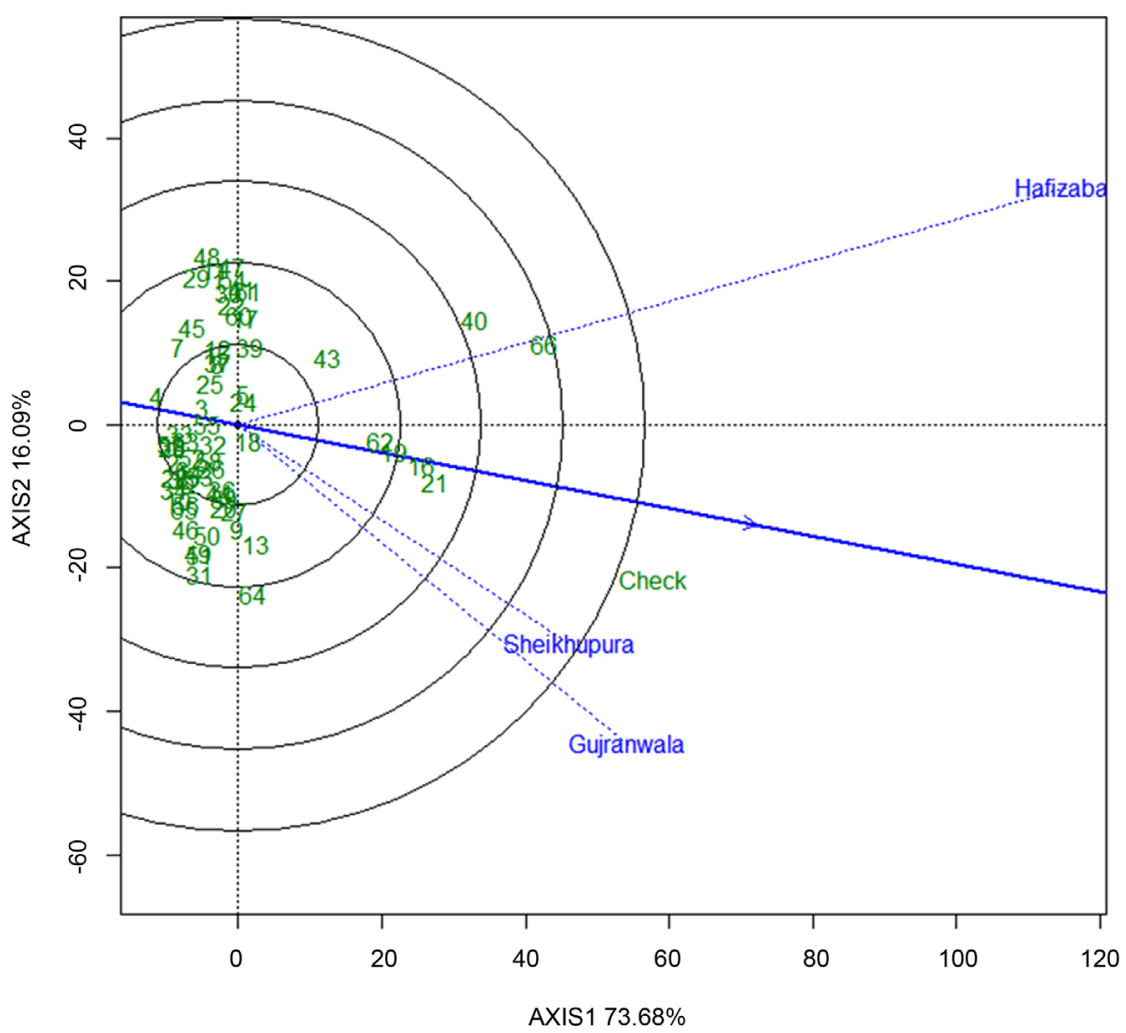

Figure 2. Performance of genotypes and IRBB lines against the disease (BLB) at three hotspots. 
maximum disease incidence in Hafizabad location as compared to other two locations, followed by entry no 40 , as indicated by farthest distance of these genotypes in biplot from center towards the vector of Hafizabad location.

The figure further emphasizes the performance of each genotype in different locations. Genotypes can be further divided into group according to their locations in GEI biplot. The biplot can be seen divided into four parts (Figure 2) by two axis, vertical mean axis and horizontal mean axis. The genotypes near the horizontal mean axis (HMA) are more stable as compared to those genotypes which are far from the HMA. Keeping in view the whole scenario, it can be depicted that performance of the genotype entry no 64 was the least stable, followed by entry no 64, 40 and 66 as indicated by their distance from HMA in the GEI biplot.

On the other hand, vertical mean axis is the measure of average disease incidence in all the target locations. The genotypes falling left to this axis showed less disease incidence than the average of disease incidence while the genotypes falling right to this axis are more susceptible. Check variety is the located far right position in the GEI biplot indicating its maximum disease incidence and maximum susceptibility to BLB disease, followed by entry no. 66, 40, 21, 16 and 19 and so on. Check variety showed unstable performance and disease incidence was higher in Gujranwala and Sheikhupura locations as compared to Hafizabad location; likewise, the susceptibility of entry 66, and 40 was also unstable in different environments and its disease incidence likelihood was more in Hafizabad location as compared to other two locations. Entry no 21 followed by 16, 19 and 62 also among the most susceptible lines with stability in susceptible performance to BLB disease in all the three locations indicating their usefulness as stable susceptible check for these locations in further experimentations.

Entry no 4, located infar left position of the GEI biplot (Figure 3) indicated its maximum resistance towards BLB disease in all the three target locations. Furthermore, the shortest vector from HMA also confirms the stable performance in all the three locations. Therefore, this line can be utilized as the most stable $B L B$ resistant line or check in these studied three target locations.

It was further emphasized by this study that Xa4 and $x a 13$ were found to deliver significant resistance against the local pathotypes of disease bacteria in studied germplasm and NILs. Among the resistant germplasm, these two genes were found in the majority as compared to other genes studied. However, some other lines as well as NILs were also found resistant carrying no gene among these studied five genes. These lines may be further studied to investigate genes that can be utilized further in these locations to breed resistant rice lines in the future.

\section{Conclusion}

The study confirms that NILs having different combination of introgressed BLB resistant $(\mathrm{Xa})$ genes can be effectively employed to incorporate horizontal resistance in local germplasm against a number of local isolates of bacterial diseases 


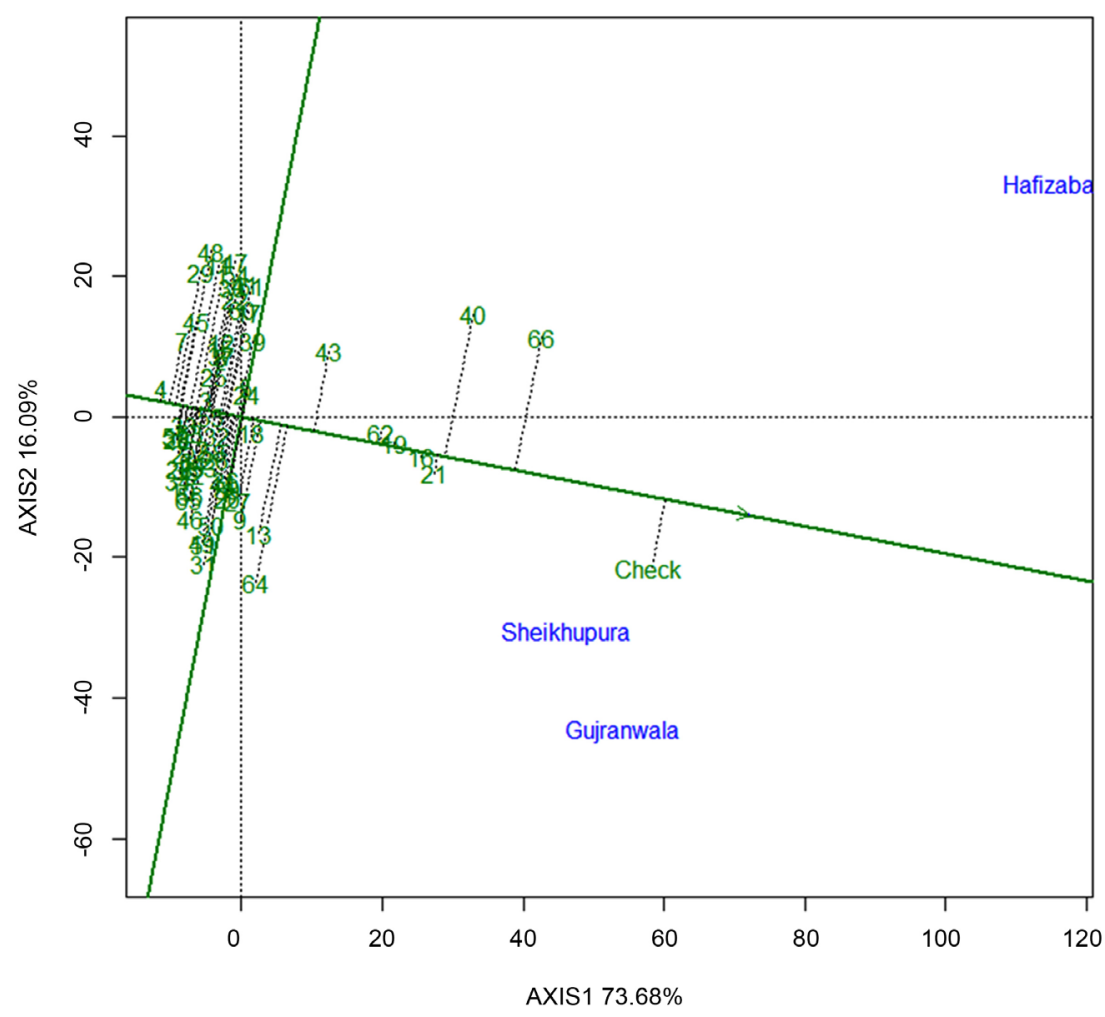

Figure 3. Stability and diversity studied of rice germplasm and BLB hotspot locations.

in crops. Furthermore, these $X a$ genes $(X a 4, X a 5, X a 7, x a 13$, and $X a 21)$ successfully developed resistance in rice germplasm and can be exploited in breeding programs to develop BLB resistant germplasm and varieties. Thirty-one (31) lines were categorized under resistant cluster, twenty-eight (28) were moderately resistant, six (6) were moderately susceptible and one (susceptible check) was in susceptible category. Grouping of different lines/varieties under same cluster shows their significantly similar response against BLB disease in corresponding environment. Among the studied NILs, only one line showed polymorphism for all five resistant genes, two lines had four; seven lines had three genes, seven lines showed di-genic while five lines showed mono-genic polymorphism. These lines with multiple-genes for BLB resistance can be evolved as a new BLB resistant variety and also be utilized as donor parent in breeding programs for developing new cultivars with horizontal resistance against more than one target pathotypes and environments. It was further emphasized by this study that Xa4 and $x a 13$ were found to deliver significant resistance against the local pathotypes in studied germplasm and NILs.

\section{Conflicts of Interest}

The authors declare no conflicts of interest regarding the publication of this paper.

\section{References}

[1] Khush, G.S. (2005) What It Will Take to Feed 5.0 Billion Rice Consumers in 2030. 
Plant Molecular Biology, 59, 1-6. https://doi.org/10.1007/s11103-005-2159-5

[2] Ishiyama, S. (1922) Studies on Bacterial Leaf Blight of Rice. Report of Agricultural Experiment Station, 45, 233-261.

[3] Ou, S.H. (1985) Rice Diseases. CAB International Mycological Institute, Kew, Surrey, U.K.

[4] Mew, T.W., Alvarez, A.M., Leach, J.E. and Swings, J. (1993) Focus on Bacterial Blight of Rice. Plant Diseases, 77, 5-12. https://doi.org/10.1094/PD-77-0005

[5] Eamchit, S. and Mew, T.W. (1982) Comparison of Virulence of Xanthomonas compastris pv. oryzae in Thailand and the Philippines. Plant Diseases, 66, 556-559. https://doi.org/10.1094/PD-66-556

[6] Singh, R.K. and Chaudhary, B.D. (1977) Biometrical Methods in Quantitative Genetic Analysis. Kalyani Publishers, New Delhi.

[7] Xia, C., Chen, H. and Zhu, X. (2012) Identification, Mapping, Isolation of the Genes Resisting to Bacterial Blight and Breeding Application in Rice. Molecular Plant Breeding, 3, 120-130. https://doi.org/10.5376/mpb.2012.03.0012

[8] Nino-Lui, D.O., Ronald, P.C. and Bogdanove, A.J. (2006) Pathogen Profile Xanthomonas oryzae Pathovars: Model Pathogens of a Model Crop. Molecular Plant Pathology, 7, 303-324. https://doi.org/10.1111/j.1364-3703.2006.00344.x

[9] Wang, C.T., Wen, G.S., Lin, X.H., Liu, X.Q. and Zhang, D.P. (2009) Identification and Fine Mapping of the New Bacterial Blight Resistance Gene, Xa31(t), in Rice, European Journal of Plant Pathology, 123, 235-240. https://doi.org/10.1007/s10658-008-9356-4

[10] Khan, J.A., Arshad, H.M.I., Jamil, F.F. and Hasnain, S. (2008) Screening of Rice Germplasm Against Bacterial Leaf Blight Disease. Pakistan Journal of Phytopathology, 20, 48-51.

[11] Singh, K., Vikal, Y., Mahajan, R., Cheema, K.K., Bhatia, D., Sharma, R., Lore, J.S. and Bharaj, T.S. (2007) Three Novel Bacterial Blight Resistance Genes Identified, Mapped and Transfer to Cultivated Rice $O$. sativa L. The 2 nd International Conference on Bacterial Blight of Rice, Nanjing, China, 1-3 October 2007, 82-84. 